\title{
New records of three hippoboscid species on newly captured birds from nature in Paraná, Brazil
}

\author{
Novos registros de três espécies de hipoboscídeos em aves recém-capturadas da natureza no Paraná, Brasil \\ Frederico Fontanelli Vaz ${ }^{1 *}$; Valéria Natascha Teixeira ${ }^{2}$

\begin{abstract}
${ }^{1}$ Centro de Triagem de Animais Silvestres, Pontifícia Universidade Católica do Paraná - PUCPR, Tijucas do Sul, PR, Brasil
${ }^{2}$ Laboratório de Parasitologia Veterinária, Escola de Ciências Agrárias e Medicina Veterinária, Pontifícia Universidade Católica do Paraná - PUCPR, Curitiba, PR, Brasil
\end{abstract}

Received April 4, 2015

Accepted August 23, 2016

\begin{abstract}
The aims of this study was to provide new records of hippoboscid flies collected over an one-year period on newly captured birds from nature in the state of Paraná, Brazil. The birds were received by a wildlife center in Tijucas do Sul and the hippoboscid flies were collect by hand or by tweezers, generating a prevalence of $0.7 \%$ (16/2232) of parasitized birds. New information about distribution of hippoboscid flies on Asio clamator, Rupornis magnirostris and Athene cunicularia was reported in the state of Paraná. The Caracara plancus, Falco peregrinus and Penelope obscura are new host species for Ornithoctona erythrocephala in the state of Paraná, and the Asio stygius for Icosta rufiventris and Ornithoica vicina in Brazil. This study provided new information about hosts and distribution of hippoboscid flies in Brazilian birds.
\end{abstract}

Keywords: Diptera, Hippoboscidae, ectoparasites, Icosta, Ornithoctona, Ornithoica.

\section{Resumo}

O objetivo deste estudo foi fornecer novos registros de hipoboscídeos coletados durante o período de um ano em aves recém-capturadas da natureza no estado do Paraná, Brasil. As aves foram recebidas pelo Centro de Triagem de Animais Silvestres localizado em Tijucas do Sul, e os hipoboscídeos foram coletados manualmente ou utilizando pinças, gerando uma prevalência de 0,7\% (16/2232) de aves parasitadas. Novas informaçôes sobre a distribuição de hipoboscídeos em Asio clamator, Rupornis magnirostris e Athene cunicularia foram observados no estado do Paraná. Caracara plancus, Falco peregrinus e Penelope obscura são novas espécies de hospedeiros para Ornithoctona erythrocephala no Paraná, e Asio stygius para Icosta rufiventris e Ornithoica vicina no Brasil. O presente estudo forneceu novas informaçóes sobre hospedeiros e distribuição de hipoboscídeos em aves brasileiras.

Palavras-chave: Diptera, Hippoboscidae, ectoparasitos, Icosta, Ornithoctona, Ornithoica.

\section{Introduction}

The members of the family Hippoboscidae, known as louse flies, are obligate ectoparasites of birds and mammals, containing about 21 genera and 213 species (DICK, 2006). They belong to the superfamily Hippoboscoidea, which contains four families of flies (RAHOLA et al., 2011). The hippoboscid flies are predominantly distributed in tropical and subtropical regions, although a small number of species have successfully spread to the Artic area (MAA, 1969).

About 26 species of hippoboscid flies were recorded on birds in Brazil, but little information exists regarding the distribution

${ }^{*}$ Corresponding author: Frederico Fontanelli Vaz. Laboratório de Ornitopatologia II, Faculdade de Medicina Veterinária e Zootecnia, Universidade de São Paulo - USP, Avenida Prof. Dr. Orlando Marques de Paiva, 87, Cidade Universitária, CEP 05508-270, São Paulo, SP, Brasil. e-mail: fredfontanelli@yahoo.com.br and hosts of these ectoparasites in the country, and more studies should be encourage (MAA, 1969; ADRIANO \& CORDEIRO, 2001; GRACIOLLI \& CARVALHO, 2003; GRACIOLLI \& BISPO, 2005; ARZUA \& VALIM, 2010).

This study aimed to provide new records of hippoboscid flies collected over a one-year period on birds in the state of Paraná, southern Brazil, which were newly captured from nature and received by a Wildlife Center (CETAS IBAMA PUCPR) in Tijucas do Sul, Paraná.

\section{Material and Methods}

All the birds received at CETAS were submitted to clinical examination soon as they arrived to the center between February 2012 and February 2013. Hippoboscid flies from each bird were 
carefully removed during clinical examination by tweezers or by hand (ARZUA \& VALIM, 2010), and were stored in tubes properly identified using $70 \%$ alcohol. Samples were collected from birds regardless of sex, but all were adults, and all the individuals that were parasitized were transported to the CETAS in wooden transport boxes with adequate air inlet holes.

Subsequently, the parasites were sent to the Veterinary Parasitology Laboratory of Pontifícia Universidade Católica do Paraná for identification. Specimens were identified using a stereomicroscope and an identification key (GRACIOLLI \& CARVALHO, 2003). The parasitological prevalence was calculated (BUSH et al., 1997). This was defined as the number of hosts parasitized with one or more hippoboscid species, divided by the number of examined birds from one host species, and for each hippoboscid species.

\section{Results}

Two thousand two hundred thirty-two birds were received at CETAS during the study period. Most received birds were Passeriformes of the families Thraupidae, Cardinalidae and Turdidae. Some Psittaciformes, Columbiformes, Falconiformes and Strigiformes species were also received. Most Passeriformes and Psittaciformes were seized in illegal trade or captivity, most Columbiformes were captured from nature, and all the birds of prey were captured from nature. These last animals were captured by official environmental agencies and environmental police, as they were found injured near highways or civilian houses.

Of 2232 birds clinically examined, only 16 individuals of seven species had hippoboscid flies on clinical examination $(0.7 \%)$. The host species with their respective parasites and their parasitological indexes and distribution are grouped in Table 1.
Most of the individuals affected were birds of prey (76.74\%). The parasitized birds were as follows: Galliformes: Cracidae: Penelope obscura Temminck, 1815; Accipitriformes: Accipitridae: Rupornis magnirostris Gmelim, 1788; Falconiformes: Falconidae: Caracara plancus Miller, 1777 and Falco peregrinus Tunstall, 1771; and Strigiformes: Strigidae: Asio clamator Viellot, 1808, Asio stygius Wagler, 1832 and Athene cunicularia Molina, 1782. Three animals

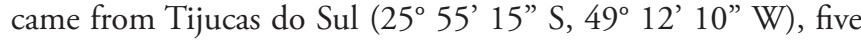
from São José dos Pinhais ( $25^{\circ} 31^{\prime} 51^{\prime}$ S, $49^{\circ} 11^{\prime} 45^{\prime} \mathrm{W}$ ), six from Curitiba $\left(25^{\circ} 25^{\prime} 42^{\prime \prime}\right.$ S, $\left.49^{\circ} 16^{\prime} 24^{\prime \prime} \mathrm{W}\right)$ and two from Ponta Grossa $\left(25^{\circ} 5^{\prime} 40^{\prime \prime} \mathrm{S}, 50^{\circ} 9^{\prime} 48^{\prime} \mathrm{W}\right)$, all in the state of Paraná, Brazil.

The hippoboscid flies were identified as Icosta rufiventris Bigot, 1885, Ornithoica vicina Walker, 1849 and Ornithoctona erythrocephala Leach, 1817. One individual of stygian owl (A. stygius) and one of $A$. clamator were simultaneously parasitized by $I$. rufiventris and $O$. vicina.

\section{Discussion}

New records of three species of hippoboscid flies on seven bird species in Brazil were observed in this study.

Prevalence studies on louse flies on birds have found a wide variety, ranging from 1\% (TELLA et al., 2000), which is in accordance with the present study (0.7\%), to 58.4\% (ADRIANO \& CORDEIRO, 2001) and 85.89\% (TELLA et al., 1998) of the birds surveyed. This variation is due to the bird community, the bird species, the collection method and the climatic conditions (YOUNG et al., 1993; SENAR et al., 1994). The low prevalence of hippoboscid flies on birds examined in CETAS over the year can be explained by different amount of received birds of each species and each order (most Passeriformes). Most of the animals

Table 1. Hippoboscid flies and host bird species found at a wildlife center located in Tijucas do Sul, Paraná, Brazil.

\begin{tabular}{|c|c|c|c|c|}
\hline Host bird species & $\mathbf{N}$ & Hippoboscid species & Prevalence (\%) & Host origin \\
\hline \multicolumn{5}{|l|}{ Accipitriformes } \\
\hline \multicolumn{5}{|l|}{ Accipitridae } \\
\hline \multirow[t]{2}{*}{ Rupornis magnirostris } & 10 & Ornithoctona erythrocephala & 40.0 & CUR/PG/SJP \\
\hline & & Ornithoica vicina & 10.0 & TS \\
\hline \multicolumn{5}{|l|}{ Falconiformes } \\
\hline \multicolumn{5}{|l|}{ Falconidae } \\
\hline Caracara plancus & 11 & Ornithoctona erythrocephala & 9.1 & SJP \\
\hline Falco peregrinus & 1 & Ornithoctona erythrocephala & 100.0 & PG \\
\hline \multicolumn{5}{|l|}{ Galliformes } \\
\hline \multicolumn{5}{|l|}{ Cracidae } \\
\hline Penelope obscura & 5 & Ornithoctona erythrocephala & 40.0 & CUR/SJP \\
\hline \multicolumn{5}{|l|}{ Strigiformes } \\
\hline \multicolumn{5}{|l|}{ Strigidae } \\
\hline \multirow[t]{2}{*}{ Athene cunicularia } & 17 & Icosta rufiventris & 5.9 & TS \\
\hline & & Ornithoica vicina & 5.9 & CUR \\
\hline \multirow[t]{2}{*}{ Asio clamator } & 15 & Icosta rufiventris & 6.7 & CUR/SJP \\
\hline & & Ornithoica vicina & 20.0 & \\
\hline \multirow[t]{2}{*}{ Asio stygius } & 2 & Icosta rufiventris & 50.0 & TS \\
\hline & & Ornithoica vicina & 50.0 & \\
\hline Total & 63 & & 25.3 & \\
\hline
\end{tabular}

$\mathrm{N}$ = number of birds examined; CUR = Curitiba; SJP = São José dos Pinhais; PG = Ponta Grossa; TS = Tijucas do Sul. 
affected by louse flies in the present study were birds of prey, which have commonly been reported as hosts of these ectoparasites (MAA, 1969), but a small number of individuals were received over the year.

Hippoboscid species recorded on Brazilian birds related to the present study include $O$. erythrocephala on Accipitriformes, Falconiformes and Strigiformes, O. vicina on Falconiformes and Strigiformes and I. rufiventris on Strigiformes (GRACIOLLI \& CARVALHO, 2003, 2005). In addition to these findings, the present study observed $C$. plancus, $F$. peregrinus and $P$. obscura as new host species for $O$. erythrocephala in the state of Paraná.

This study also provided new information about distribution of hippoboscid flies on $A$. clamator, $R$. magnirostris and $A$. cunicularia in the state of Paraná. The stygian owl is a new host species for hippoboscid flies in Brazil. Graciolli \& Bispo (2005) found hippoboscid species on wild owls in Paraná, at a prevalence of $16.7 \%$, which is in agreement with the prevalence in parasitized Strigiformes species of the present study (17.6\%). In the same way, Young et al. (1993) evaluated 382 wild owls in northwestern California and found 148 hippoboscid flies on 62 (17\%) of the birds.

The intensity of parasites was not calculated in this study because the birds were captured in the wild and transported to CETAS, probably losing some specimens on the way, as louse flies leave their host during capture (ARZUA \& VALIM, 2010). In addition, most parasitized birds were injured and would be submitted to clinical procedures, and appropriate collection methods to obtain quantitative data would be extra stressful for the patients, probably leading them to death.

This study enabled identification of new records of three species of hippoboscid flies on birds from a wildlife center, southern Brazil, and more information about relations between host and ectoparasites were provided.

\section{Acknowledgements}

We gratefully acknowledge Dr. Ana Carolina Fredianelli and Dr. Grazielle Cristina Garcia Soresini for technical support in the Wildlife Center (CETAS IBAMA PUCPR), Tijucas do Sul, Paraná, Brazil.

\section{References}

Adriano EA, Cordeiro NS. Prevalence and intensity of Haemoproteus columbae in three species of wild doves from Brazil. Mem Inst Oswaldo Cruz 2001; 96(2): 175-178. http://dx.doi.org/10.1590/S0074-02762001000200007. PMid:11285493.

Arzua M, Valim MP. Bases para o estudo qualitativo e quantitativo de ectoparasitos em aves. In: Matter SV, Straube FC, Piacentini VQ, Accordi IA, Cândido JF Jr. Ornitologia e conservação: ciência aplicada, técnicas de pesquisa elevantamento. 1st ed. Rio de Janeiro: Technical Books; 2010. p. 349-365.

Bush AO, Lafferty KD, Lotz JM, Shostak AW. Parasitology meets ecology on its own terms: Margolis et al. revisited. J Parasitol 1997; 83(4): 575-583. http://dx.doi.org/10.2307/3284227. PMid:9267395.

Dick CW. Checklist of world Hippoboscidae (Diptera: Hippoboscoidea). Chicago: Field Museum of Natural History; 2006.

Graciolli G, Bispo AA. Hippoboscidae (Diptera) ectoparasitos sobre seis espécies de corujas (Strigiformes) no estado do Paraná, Sul do Brasil. Rev Bras Ornitol 2005; 13(2): 181-182.

Graciolli G, Carvalho CJB. Hippoboscidae (Diptera, Hippoboscoidea) no Estado do Paraná, Brasil: chaves de identificaçáo, hospedeiros e distribuição geográfica. Rev Bras Zool2003; 20(4): 667-674. http://dx.doi.org/10.1590/ S0101-81752003000400019.

Maa TC. A revised checklist and concise host index of Hippoboscidae (Diptera). Pac Insects Monogr 1969; 20: 261-299.

Rahola N, Goodman SM, Robert V. The Hippoboscidae (Insecta: Diptera) from Madagascar, with new records from the "Parc National de Midongy Befotaka”. Parasite 2011; 18(2): 127-140. http://dx.doi.org/10.1051/ parasite/2011182127. PMid:21678788.

Senar JC, Copete JL, Domenech J, Walter GV. Prevalence of louse-flies Diptera, Hippoboscidae parasiting a cardueline finch and its effect on body condition. Ardea 1994; 82(1): 157-160.

Tella JL, Gajón A, Gortázar C, Osácar JJ. High host specificity of Crataerina melbae (Diptera: Hippoboscidae) in a mixed colony of birds. J Parasitol 1998; 84(1): 198-200. http://dx.doi.org/10.2307/3284563. PMid:9488370.

Tella JL, Rodríguez-Estrella R, Blanco G. Louse flies on birds of Baja California. JWildl Dis 2000; 36(1): 154-156. http://dx.doi.org/10.7589/0090-355836.1.154. PMid:10682758.

Young KE, Franklin AB, Ward JP. Infestation of northern spotted owls by hippoboscid (Diptera) flies in Northwestern California. $J$ Wildl Dis 1993; 29(2): 278-283. http://dx.doi.org/10.7589/0090-3558-29.2.278. PMid:8487378. 